\title{
Karst sinkhole mapping using GIS and digital terrain models
}

\author{
Peter Brøgger Sørensen, Holger Lykke-Andersen, Peter Gravesen and Bertel Nilsson
}

Danish glacial landscape elements such as basal till plains, hummocky moraine areas and outwash plains contain a variety of small and large depressions. They were probably formed in glacial, late-glacial or Holocene time and may represent dead-ice holes or degraded pingos, or sinkholes formed by interaction between pre-Quaternary chalk or limestone bedrock and the thin glacial cover. The aim of this study is to map terrain depressions that might potentially be karst sinkholes by analysing digital terrain models in the geographic information system (GIS). The incentive to apply the technique for mapping of sinkholes came from an accidental acquaintance with a farmer, Jens Kirk, whose farmland is located near Thisted. Jens Kirk told us that the front end of his tractor had suddenly sunk into the ground during routine farming work, and this incident was our inspiration to start the project described here.

\section{Geological setting and study areas}

Sinkholes have previously been registered in mainly northern Denmark where the pre-Quaternary surface consists of chalk and limestone (Feddersen 1880). In these areas sinkholes and other karst features including dolines, karst lakes, small caves, disappearing streams and karst springs are known (Nilsson \& Gravesen 2017). The landforms are found at locations where Quaternary surface layers are thin and calcareous rocks are present near the surface. Sinkholes can be formed when acid groundwater dissolves and removes calcium carbonate from the calcareous sediment. Cavities are formed in the carbonate sediments, and the overlying deposits may collapse and create a surface depression. The present authors have carried out pilot studies around Limfjorden and in the northern part of Djursland in Jylland. The results from north of Thisted and in the planted wood of Svinkløv Plantage south of Svinkløv are presented here (Fig. 1). It should be noted, that Svinkløv Plantage has never been farmed, and the depressions found here are small compared to those in farmed areas. This means that even small depressions have been preserved if not covered by drifting sand.

The first study area is located $2-3 \mathrm{~km}$ north of Thisted (Fig. 1). The pre-Quaternary surface of Maastrichtian chalk and Danian bryozoan limestone and micritic limestone in this area is commonly covered by a thin (less than $5 \mathrm{~m}$ thick) Quaternary cover. Small dolines filled with Paleocene clay are found in the Danian limestone in
Fig. 1. Locations of mapped small depressions in northern Jylland. The surface is shown as pre-Quaternary where parts of it consists of Cretaceous chalk and Danian limestone covered by Quaternary deposits. Red and blue dots: possible sinkholes mapped with the 1.6 and $0.4 \mathrm{~m}$ digital elevation models, respectively. Black frames: local study areas.

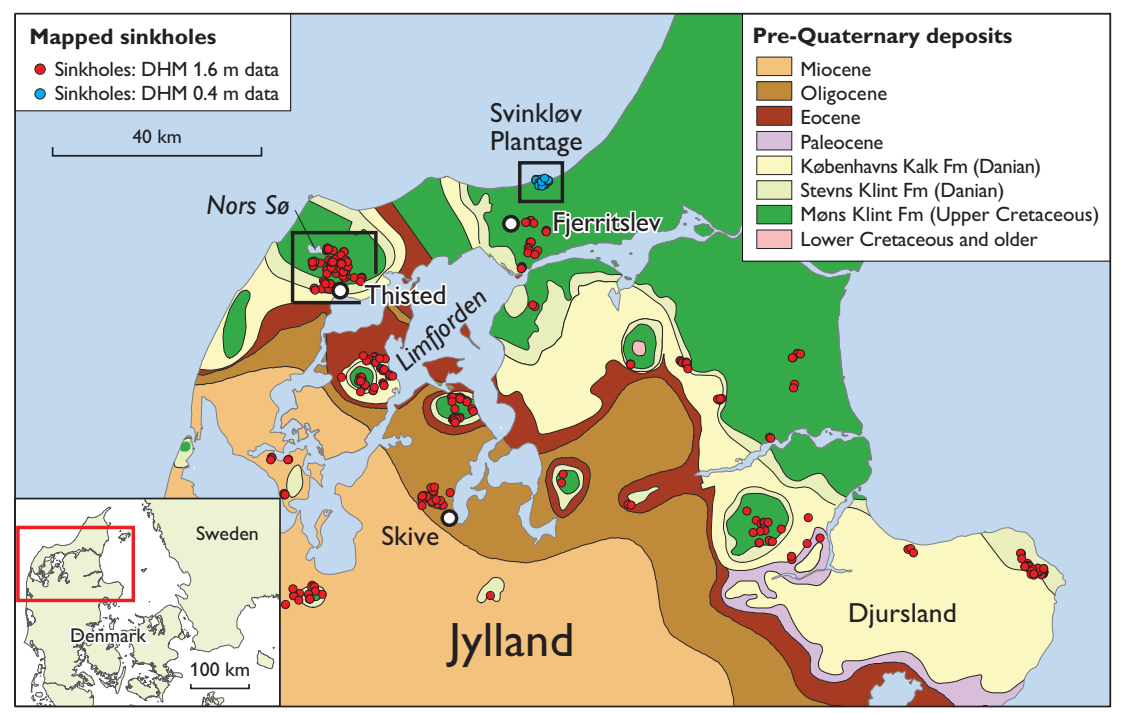


Thisted town (Gravesen \& Jakobsen 2016). Sinkholes are distributed over the entire area. In cliffs and limestone pits it is possible to find two types of dolines: Funnel-shaped and vertical-sided. Both types have originated as areas of intense fracturing where acid water has percolated downwards and dissolved the chalk. In the western part of the area, large karstic lakes such as Nors Sø occur along a fault zones and in the middle of a salt structure (Hansen \& Håkansson 1980). Between Svinkløv and Fjerritslev on the north-west coast of Jylland many sinkholes and dolines are registered in the chalk and limestone cliffs (Gry 1979). Sinkholes also occur in the area of elevated chalk south of Fjerritslev.

\section{Methods and data}

The detailed topographic maps that became available from c. 1900 made it possible for Ussing (1903) and Harder (1908) to interpret the Danish glacial landscape. Since then the technological evolution has resulted in a highly detailed digital terrain model (in Danish 'digital højdemodel', DHM) with a lateral resolution of $1.6 \mathrm{~m}$ in the 2007 version (DHM 1.6) and $0.40 \mathrm{~m}$ in the 2016 version (DHM 0.4) with a vertical accuracy of a few centimetres (www.sdfe.dk). Using hill-shade versions of the DHM 1.6 model with a vertical exaggeration of 3 even the smallest vertical variations can be detected. Numerous depressions were identified, and detailed mapping was initiated, using QGIS (open source version of GIS) as a data repository. The DHM 0.4 model is delivered with hill shade but with no vertical exaggeration.

The 3D geographical information of the mapped depressions was analysed in GIS supported by other sources of spatial data such as orthophoto and topographic maps. Mobile devices such as tablets and smartphones with GPS were used in the field documentation of the depressions throughout the mapping project. Two of the authors recently demonstrated the usefulness of the combination of these techniques for identification and mapping of remnants of pingos in Denmark (Sørensen \& Lykke-Andersen 2017).

More than 350 depressions supposed to be sinkholes in northern Jylland were mapped (Fig. 1); in Svinkløv Plantage sinkholes were mapped using the DHM 0.4 model. The digital terrain models were provided by the Danish Agency for Data Supply and Efficiency (www.sdfe.dk) as a digital service in raster format with and without hill shade for visual interpretation, and as a web map service for analysis and measurement.
The depression mapping was divided into three steps. Firstly, the location of each depression was found and digitised using GIS. Secondly, a profile of the depression was constructed using the QGIS profile tool and its diameter and depth measured, allowing a descriptive statistical analysis of the sinkholes and their spatial distribution. Inspection of orthophotos was sometimes helpful because the vegetation pattern can reveal differences in the topsoil. On this basis the depression was either approved or rejected. For example, a shallow depression on an inclined surface facing away from the incident light produces a significant shadow which does not represent a sinkhole. Finally, a field check was carried out for some of the proposed sinkholes, because previous studies have shown that the structural and sedimentary conditions of some of the depressions should be investigated by excavation (Zhu et al. 2014).

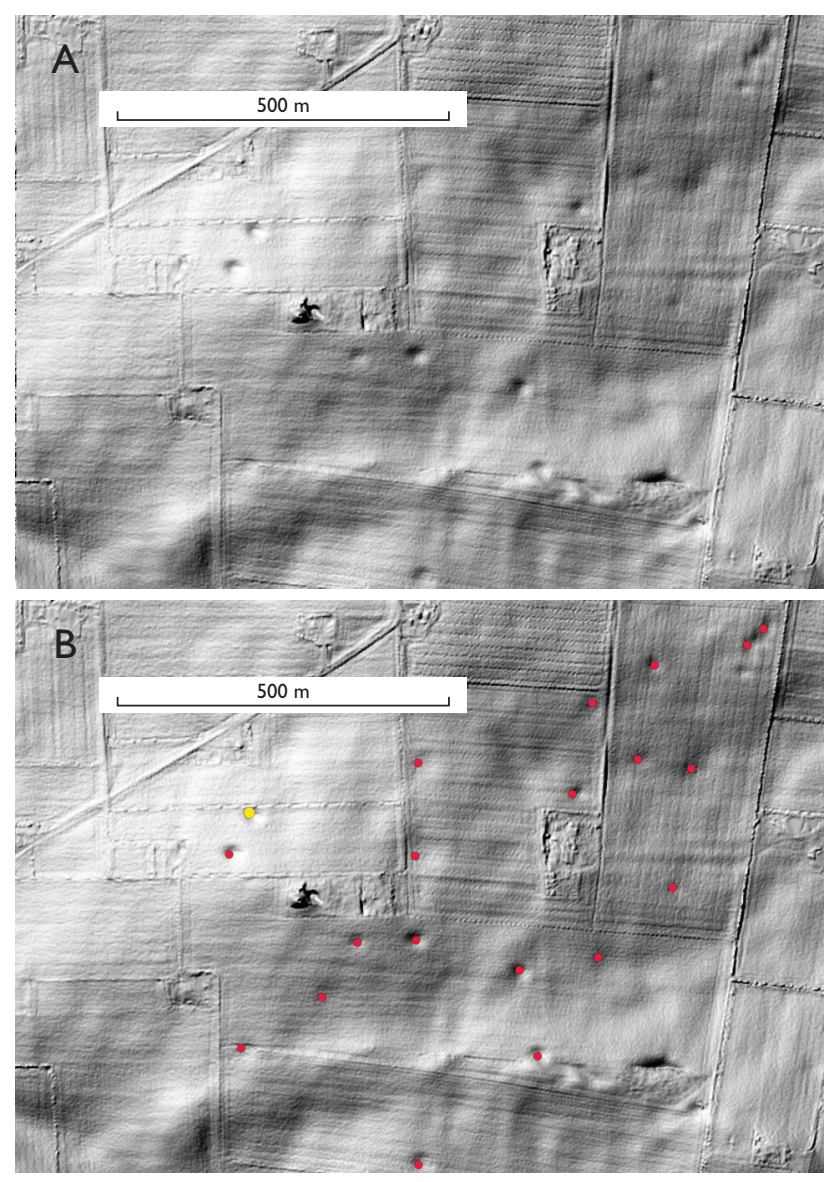

Fig. 2. Hill-shade map with $10 \times$ vertical exaggeration showing examples of sinkholes mapped with the $1.6 \mathrm{~m}$ digital elevation model. A: Unmarked map. B: Mapped sinkholes (red dots). Yellow dot: location of the excavated 'Jens Kirk sinkhole' north of Thisted as shown in Fig. 3. 


\section{Results}

Results from the depression mapping north of Thisted and in Svinkløv Plantage are shown in Figs 2 and 3. In the Thisted area $c .116$ sinkholes are identified, and 20 depressions were identified on the hill shade map within the subarea measuring $1 \times 1.5 \mathrm{~km}$ shown in Fig. 2. The diameter of the depressions in the Thisted area varies from 21 to 100 $\mathrm{m}$, with depths between 0.3 and $2.5 \mathrm{~m}$. To obtain information about the geometry of the depression encountered by Jens Kirk and to prove it is a sinkhole, a trench was dug (Fig. 3). The diameter of the excavated depression is $25 \mathrm{~m}$. Outside the depression, the depth below the topsoil to the chalk surface was $30 \mathrm{~cm}$. In the middle of the depression the chalk surface occurs about $2.35 \mathrm{~m}$ below the terrain surface outside the sinkhole. In the south-western part of the profile, the chalk surface is almost vertical, indicating subsidence along a fault. Stone-free topsoil, probably glacial, was found overlaying the chalk. In the middle of the depression about $40 \mathrm{~cm}$ above the chalk surface, a chert layer $7 \mathrm{~m}$ long and 5-10 cm thick was found. The geometry and structure of the depression strongly indicate that it is a karstic sinkhole. It should be noted that the diameter of the 'Jens Kirk sinkhole' (Fig. 3A) is in the lower range of those mapped north of Thisted.

In Svinkløv Plantage, 65 small sinkholes were mapped with success using the DHM 0.4 model (Fig. 4), which are not visible in the $1.6 \mathrm{~m}$ model; the area is partly covered by dune sand. The diameter of the small sinkholes varies from 1 to $10 \mathrm{~m}$, with depths between 0.4 and $4.5 \mathrm{~m}$. A survey in the Bulbjerg area has revealed a few similar small depressions that are likewise supposed to be sinkholes. The

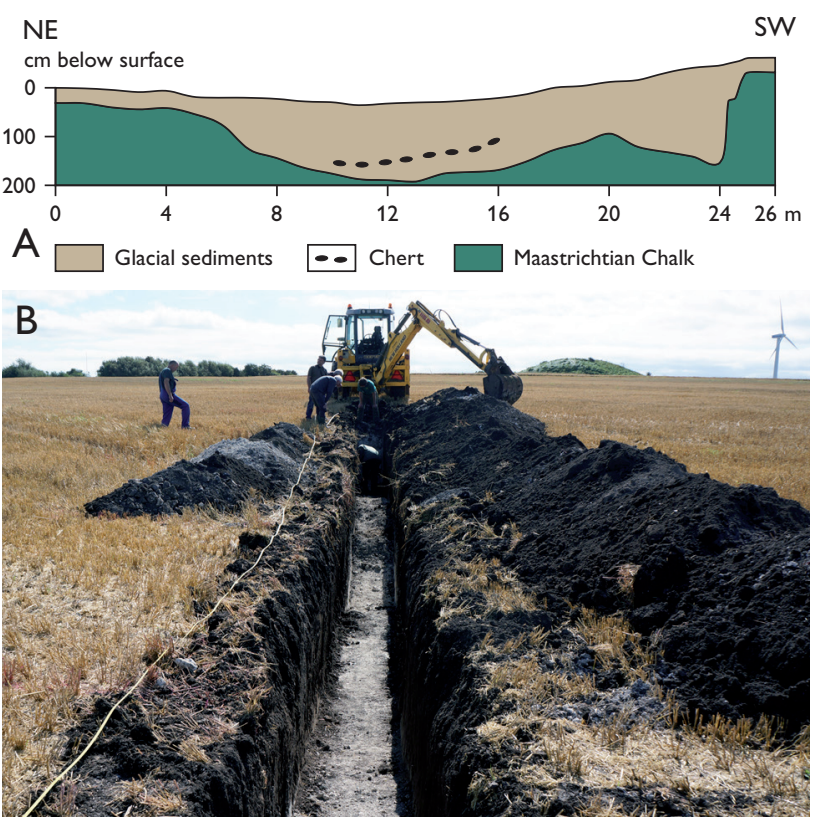

Fig. 3. A: Section drawn from the excavated trench through the 'Jens Kirk sinkhole' (vertical exaggeration $1.7 \times$ ). B: The excavated trench with the chalk surface exposed at the bottom. UTM coordinates: 481294E, 6316209N.

DHM 0.4 model is obviously better suited for the minor landscape elements such as the small depressions found in Svinkløv Plantage even with the absence of vertical exaggeration.

A significant difference in the diameter/depth ratio between the sinkholes in the Thisted and Svinkløv Plantage areas is seen in Table 1. The sinkholes in Svinkløv Plan-
Fig. 4. Sinkholes (red dots) mapped in Svinkløv Plantage using the $0.4 \mathrm{~m}$ digital elevation model.

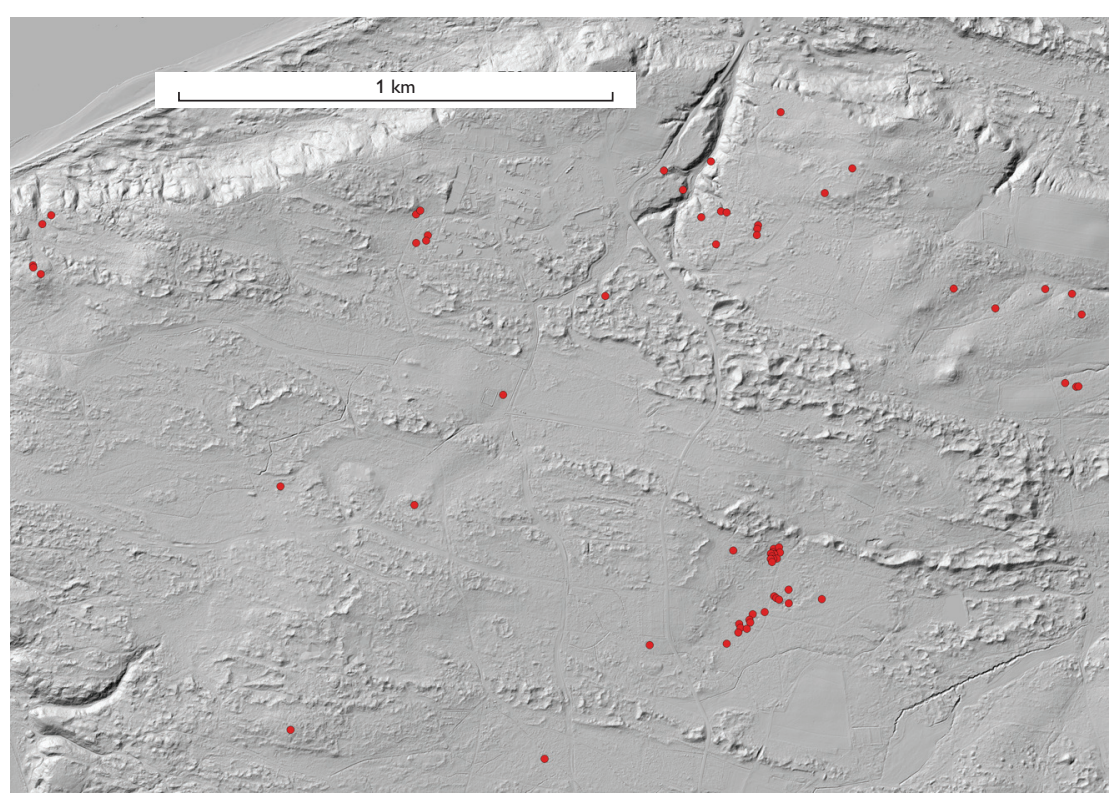


Table 1. Depths and diameters of sinkholes

\begin{tabular}{lccc}
\hline & Depth, $\mathrm{m}^{\S}$ & Diameter, $\mathrm{m}^{\S}$ & Diameter/Depth \\
Thisted & $0.3-2.5(0.8)$ & $21-100(43.6)$ & 57.4 \\
Svinkløv Plantage & $0.4-4.5$ & $1.0-10(4.3)$ & 3.8 \\
\hline
\end{tabular}

§Minimum, maximum and mean values

tage are ten times smaller but slightly deeper than those in Thisted.

\section{Discussion \\ Origin of the mapped depressions}

Mapping of karst sinkholes using GIS and DHM in areas with carbonate sediments underlying thin Quaternary deposits seems to be evident. However, the mapping in this study also identified depressions in areas with Palaeogene clays underneath thin glacial deposits (area west of Skive; Fig. 1). These depressions cannot have been developed due to karst evolvement. Thus, dead-ice holes or degraded pingos can be other potential origins of these depressions and have thoroughly been discussed in Sørensen \& LykkeAndersen (2017). However, it is beyond the scope of this study to collect the required structural and sedimentary documentation to classify all of the individual depressions found in northern Jylland.

\section{Factors influencing the formation and geometry of the mapped sinkholes}

Sinkholes may develop if the Pre-Quaternary surface consists of carbonate sediments such as Maastrichtian chalk or Danian limestone, which are easily dissolved and contain fractures, hollows and cavities. In order to allow the sinkhole-forming process to operate during the Neogene, the overlying sediments (mainly Quaternary deposits) must be thin. The circular shape of the sinkholes is possibly a combination of crossing fault lines and dissolution processes. The anthropogenic activity seems to be an important factor for the collapses, but also the climate with changing wet and dry conditions may influence the development. Changes in the groundwater level, abstraction of water and changing drainage patterns are other controlling factors.

\section{Conclusions}

1. The pilot study demonstrates that analysing digital terrain models in GIS is a powerful method. The DHM 1.6 model with a vertical exaggeration of 3 is very well suited for the identification of depressions with diameters greater than $20 \mathrm{~m}$, while the DHM 0.4 model is better suited for the identification of small landscape elements even without vertical exaggeration.

2. The sinkholes in Svinkløv Plantage are much smaller and slightly deeper than in Thisted. One explanation for this could be that the Svinkløv area has never been farmed.

3. The structural and sedimentary conditions in other sinkholes should be investigated by excavations.

\section{References}

Feddersen, A. 1880: Nogle danske Overfladeforhold. Geografisk Tidsskrift 4, 113-118.

Gravesen, P. \& Jakobsen, P.R. 2016: Pre-Quaternary rocks and sediments with some of the highest radioactive levels in Denmark. Bulletin Geological Survey of Denmark and Greenland 35, 31-34.

Gry, H. 1979: Description of the geological map of Denmark. Map sheet Løgstør. Quaternary deposits. 1:100 000/1:50 000 (in Danish with English summary). Danmarks Geologiske Undersøgelse I. Række 26, 58 pp. + atlas + map vol.

Hansen, J.M. \& Håkansson, E. 1980: Thistedstrukturens geologi - et 'neotektonisk' skoleeksempel. Dansk Geolologisk Forening, Årsskrift for 1979, 1-9.

Harder, P. 1908: En østjydsk Israndslinje og dens Indflydelse paa Vandløbene. Danmarks Geologiske Undersøgelse II. Række 19, 262 pp.

Nilsson, B. \& Gravesen, P. 2017: Karst geology and regional hydrogeology in Denmark. In: White, W.B. et al. (eds): Karst Groundwater Contamination \& Public Health. Springer International Publishing AG Switzerland (in press).

Sørensen, P.B. \& Lykke-Andersen, H. 2017: Kortlægning af pingo-rester i Danmark. Geologisk Tidsskrift 2017, 21-29.

Ussing, N.V. 1903: Om Jyllands Hedesletter og Teorierne for deres Dannelse. Oversigt over Det Kongelige Danske Videnskabernes Selskabs Forhandlinger 1903(2) 99-152.

Zhu, J., Taylor, T.P., Currens, J.C. \& Crawford, M.M. 2014: Improved karst sinkhole mapping in Kentuckey using LIDAR techniques: A pilot study in Floyds Fork watershed. Journal of Cave and Karst Studies 76(3) 207-216.

\footnotetext{
Authors' addresses

P.B.S., Mollepold 17, 6200 Aabenraa,Denmark. E-mail: peter@peterbrogger.dk

H.L.-A., Department of Geoscience, Aarhus University, Høegh Guldbergs Gade 2, 8000 Aarhus C, Denmark.

P.G. \& B.N., Geological Survey of Denmark and Greenland, Øster Voldgade 10, Copenhagen K, Denmark.
} 